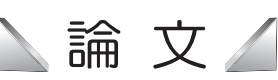

Original Paper

\section{来待砂岩の極低温下における力学挙動*}

\author{
鴨志田直人 ${ }^{1}$ 大 河原正文 ${ }^{2}$ \\ 阿部 正 良 ${ }^{3}$ 古 住 光 正 $^{4}$
}

\title{
Mechanical Behavior of Kimachi Sandstone under Ultralow Temperature
}

\author{
by Naoto KAMOSHIDA ${ }^{\mathrm{a}^{*}}$, Masafumi OKAWARA ${ }^{\mathrm{a}}$, Masayoshi $\mathrm{ABE}^{\mathrm{a}}$ and Mitsumasa FURUZUMI ${ }^{\mathrm{a}}$
}

a. Faculty of Engineering, Iwate University, 4-3-5 Ueda, Morioka, Iwate 020-8551, Japan

(*Corresponding author E-mail: kamosida@iwate-u.ac.jp)

\begin{abstract}
The practical application of the rock cavern storage of liquefied fuels (such as natural gas, liquid hydrogen or dimethyl ether) requires stability analysis of the cavern in question with regard to thermal stress, and an understanding of thermophysical properties and mechanical properties of rock mass is essential for such analysis.

In our research, a linear expansion strain measurement test up to $-170^{\circ} \mathrm{C}$ was first conducted using Kimachi sandstone $(24.0 \%$ porosity) to study the relationship between the freezing of pore water and its expansion strain. Then a uniaxial compression test and indirect tensile test were conducted with wet sandstone cooled down below freezing point to ultralow temperatures to review the influence of the formation of pore ice on the strength of wet sandstone. The following findings were obtained.

When Kimachi sandstone is cooled down, frost swelling occurs twice, and therefore the linear expansion coefficient fluctuates over range of temperatures between 0 to $-70^{\circ} \mathrm{C}$. This may be because pores of two different sizes exist in Kimachi sandstone and the freezing temperature of the pore water differs depending on the pore size. The compressive strength and indirect tensile strength of the wet sandstone increase with the decrease in the specimen temperature. Two causes of this phenomenon may be identified. One is that an increase in pore ice that shares the load is the main cause of the phenomenon in temperatures down to $-50^{\circ} \mathrm{C}$ where freezing of the pore water is almost completed. The other is that an increase in strength by volumetric shrinkage of the rock forming minerals and pore ice is the main cause in temperatures below $-50^{\circ} \mathrm{C}$
\end{abstract}

KEY WORDS: Wet Sandstone, Ultralow Temperature, Pore Ice, Thermal Expansion Strain, Linear Expansion Coefficient, Tensile Strength

\section{1. は じめに}

地球温暖化ガス排出に関心が高まりつつある昨今において，石 炭や石油などに比べ相対的に環境負荷が少ないクリーンなエネル ギーである天然ガスの需要拡大が見込まれている。また，石油の 代替エネルギーとして液化水素やジメチルエーテルなどの低温液 化燃料の実用化も検討されている ${ }^{1)}$ 。これら石油代替エネルギー の安定供給の実現には，貯蔵施設の確保が課題となる。国土が狭 く山地が多い我が国の大規模貯蔵施設においては，地上タンク方 式や半地下タンク式のように広大な平地や海岸埋立地を必要とせ ず，隔離性および而震性に優れた地下岩盤空洞内貯蔵が有力視さ れている。さらに, 天然ガスや液化水素, ジメチルエーテルなど は通常常圧低温状態の液体として輸送するため, そのまま低温の 液化状態で貯蔵する方がエネルギー効率の観点からも都合がよ

*2010 年 4 月 20 日受付 2010 年 10 月 19 日受理

1. 普通会員 博 ( 工) 岩手大学助教工学部社会環境工学科

2. 博 (工) 岩手大学准教授 工学部社会環境工学科

3. 岩手大学技術専門員 技術部工学系技術室

4. 工学博士岩手大学名誉教授

[ 著者連絡先 ] FAX: 019-621-6446 (岩手大学・鴨志田) E-mail: kamosida@iwate-u.ac.jp

キーワード : 湿潤砂岩，極低温下，間隙水，凍結膨張ひずみ，線膨張係数， 引張強度
い。以上のことを踏まえ，液化燃料を常圧低温下で貯蔵する岩盤 内貯蔵施設の重要性が認識されている。

極低温夜化燃料の岩盤内貯蔵方式には，貯蔵槽周辺岩盤に凍結 ゾーンを設けることで液密性を確保する「凍結方式」と，貯蔵槽 周辺岩盤に不飽和ゾーンを設け貯蔵槽内側に貼った薄膜で液密性 を確保する「メンブレン方式」の 2 方式が考案されている。いず れの方式においても，貯蔵槽周辺の岩盤は冷却されるため，低温 岩盤貯蔵施設の実用化には, 空洞周辺に発生する熱応力に対する 空洞の安定性と，貯蔵した液化燃料の外部一の漏洩に対する検討 の 2 つが必要であり, その安定解析には岩盤の熱物性と力学物性 值の把握が重要となる。

岩石の低温下における熱力学的性質についての研究は, 安定解 析の際に必要となる各種物性值そのものに主眼がおかれ，沢入花崗 岩・江持安山岩 ${ }^{2)}$, 稲田花崗岩 ${ }^{3)}$, 七浦層砂岩 ${ }^{4)}$, 大谷凝灰岩 ${ }^{5)}$, 来待砂岩・伊豆若草凝灰岩 6 ) など, さまざまな岩石の物性值が 報告されている。この低温下における岩石の力学的物性值の変化 は間隙水の凍結によるものと考えられることから, 岩石の間隙率 と低温下における力学的物性值との関係についても 2 つの手法に よって研究が行われている。一つは, インタクト岩石を加熱処理 することで人工的に間隙率を変えた岩石を用いて比較する手法 ${ }^{3}$ ， もう一つは，間隙率の異なる岩石を用いて比較検討する手法 7 
Table 1 Properties of Kimachi sandstone.

\begin{tabular}{ccc}
\hline Dry density & $\left(\mathrm{g} / \mathrm{cm}^{3}\right)$ & 1.95 \\
\hline Saturated density & $\left(\mathrm{g} / \mathrm{cm}^{3}\right)$ & 2.19 \\
\hline Effective porosity & $(\%)$ & 24.0 \\
\hline Water content* & $(\%)$ & 12.3 \\
\hline Velocity of P-wave & $(\mathrm{km} / \mathrm{s})$ & 2.54 \\
\hline Velocity of S-wave & $(\mathrm{km} / \mathrm{s})$ & 1.58 \\
\hline & & $*$ Saturation state
\end{tabular}

である。稲田ら ${ }^{7)}$ は, 花崗岩 (間隙率 $1.99 \%$ ), 砂岩 $(8.12 \%)$, 凝灰岩 $(37.09 \%)$, 泥岩 $(39.42 \%)$ を用いた研究により, 間隙率の 大きい湿潤岩石ほど, 冷却による圧縮強度および引張強度の増加 は顕著になること，とくに間隙率が $37 \%$ 以上とより大きい場合 には, 湿潤岩石の圧縮強度および引張強度は乾燥岩石を超えるこ とを明らかにした。

温度低下における湿潤岩石の強度増加のメカニズムについて は, 間隙水の凍結温度とそれ以下の温度に分けて仮説が述べられ ている。間隙水の凍結にともなう岩石の強度増加メカニズムにつ いては, 水が造岩鉱物の膠着物質として働くこと, 水と造岩釷物 が荷重を分担することの複合によるものと考えられる ${ }^{7,8)}$ 。また, 間隙水凍結後の温度低下にともなう岩石の強度増加メカニズムに ついては, 間隙水の水点降下現象による孔径の大きい間隙から順 に氷結すること, 水自体の強度が温度の低下にともない増加す ることの 2 点が主たる要因であると考えられている $\left.{ }^{2}, 7,8\right)$ 。な お, この他にも, 応力腐食による亀裂速度の低下からの考察 ${ }^{9}$ や, インクルージョンモデルを用いた検討 ${ }^{10)}$ などのメカニズムがあ り, 現在のところ, 間隙水の凍結による岩石の強度増加メカニズ ムが明らかにされているとは言えない。

本研究では, 来待砂岩を用い, 極低温下における岩石の物性に ついて検討を行った。具体的には，まず始めに，線膨張ひずみ測 定試験を行い，極低温までの冷却過程における来待砂岩の変形挙 動について観察し, 間隙水の成長過程について検討した。次に, 水点下から極低温下まで泠却した供試体に対して一軸圧縮試験お よび圧裂引張試験を行い, 間隙水の生成が来待砂岩の力学物性に どのような影響を及ぼすのかについて検討した。なお，供試岩石 として来待砂岩を用いたのは, 一般的な砂岩と比較して間隙率が 高いという特徵を有するため, 間隙水の影響がより明瞭に現れる と考えられるからである。

\section{2. 実 験 方 法}

\section{$2 \cdot 1$ 供試岩石}

本研究では, 供試岩石として来待砂岩 (島根県松江市産) を用 いた。来待砂岩は, 主に円磨度の低い火山岩片と, 石英, 斜長石, 輝石，角閃石などの砂粒からなり，砂粒間は斜プチロル沸石とス メクタイトで膠着されている凝灰質砂岩である。Table 1 に来待 砂岩の物性值を示す。来待砂岩の空隙率は $24.0 \%$ と一般的な砂岩 と比較して高い特徴を有する。

供試体の形状および寸法を，線膨張ひずみ測定試験用として堆 積面を面に持つ 1 辺 $50 \mathrm{~mm}$ の立方体, 一軸圧縮試験用として堆 積面を上下端面にもつ直径 $30 \mathrm{~mm}$ 長さ $60 \mathrm{~mm}$ の円柱状, 圧裂引 張試験用として直径 $60 \mathrm{~mm}$ 長さ $30 \mathrm{~mm}$ の円柱状とした。線膨張 ひずみ測定試験に立方体供試体を用いたのは, 堆積面に平行な面 と垂直な面の線膨張ひずみを 1 つの供試体で一度に測定すること で，堆積岩の異方性を明確にするためである。各供試体にひずみ ゲージを張り付けた後, 温度 $90^{\circ} \mathrm{C}$ の乾燥炉で 48 時間以上乾燥さ せたものを乾燥状態 (飽和度 $0 \%$ ) として扱った。また, 乾燥状

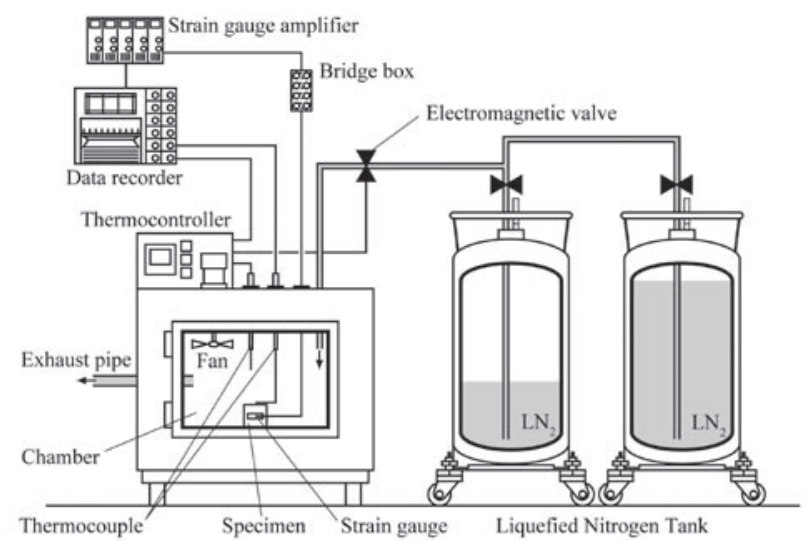

Fig.1 Schematic of experimental apparatus.

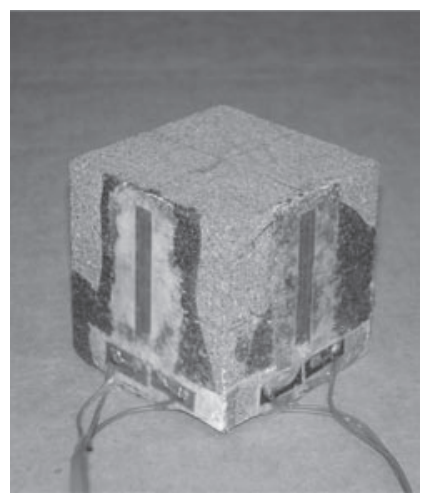

(a) Photograph

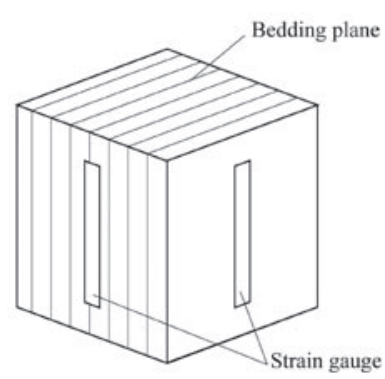

(b) Schematic
Fig.2 Specimen of linear thermal expansion test.

態の供試体を室温の蒸留水に沈め, 真空ポンプを用いて 24 時間 以上脱気しながら水中養生したものを湿潤状態 (飽和度 100\%) として扱った。

\section{$2 \cdot 2$ 線膨張ひずみ測定試験}

線膨張ひずみ測定試験には, 熱伝導率測定用低温槽 (ジャパン サーモティック社製，恒温槽 $65 \times 45 \times 40 \mathrm{~cm})$ を用いた。本実 験システムの概要を Fig. 1 に示す。本装置は, 冷媒として液化窒 素ボンベから導入した気化窒素ガスを用いる。また, 本装置の冷 却速度・昇温速度は, 熱伝対による恒温槽内部の温度測定と電磁 弁による冷媒の流入量制御により，自由に設定できる。

供試体のひずみは低温用ひずみゲージ ( 共和電業社製 KFL-30350-C1-11) を用いて, また, 供試体の表面温度はシース熱電対 (助 川電気工業社製 $\mathrm{K}$ 型熱電対 ) を用いて測定し，データロガーに 記録した。なお，ひずみゲージの貼り付け位置と向きは，Fig. 2 に示す通りである。本実験で得られた出力ひずみは，ひずみゲー ジの見かけひずみを含んでいるため，温度補正を行い，真ひずみ を求めた。なお, ひずみゲージの見かけひずみは, 石英溶融ガラ スに低温用ひずみゲージを張り付けて計測し, 計測された出力ひ ずみから温度依存性が極めて小さい石英溶融ガラスの線膨張ひず みを減算することで求めた。

線膨張試験は, 冷却速度を $3^{\circ} \mathrm{C} / \mathrm{min}$ と $0.3^{\circ} \mathrm{C} / \mathrm{min}$ の 2 段階で行っ た。冷却速度 $3^{\circ} \mathrm{C} / \mathrm{min}$ の試験では恒温槽内部の温度を室温から$170^{\circ} \mathrm{C}$ まて泠却し, $0.3^{\circ} \mathrm{C} / \mathrm{min}$ の試験では試験時間の都合上, 室温 から $-80^{\circ} \mathrm{C}$ まで冷却した。このとき, 供試体内部の温度分布が一 様になるのを待つため, 冷却速度 $3^{\circ} \mathrm{C} / \mathrm{min}$ では- $170^{\circ} \mathrm{C}$ を, $0.3^{\circ} \mathrm{C} /$ 


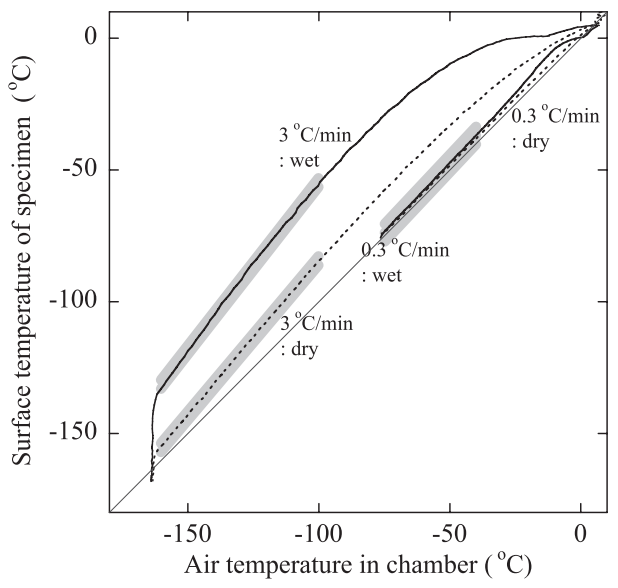

Fig.3 Relationship between air temperature in chamber and surface temperature of specimen.

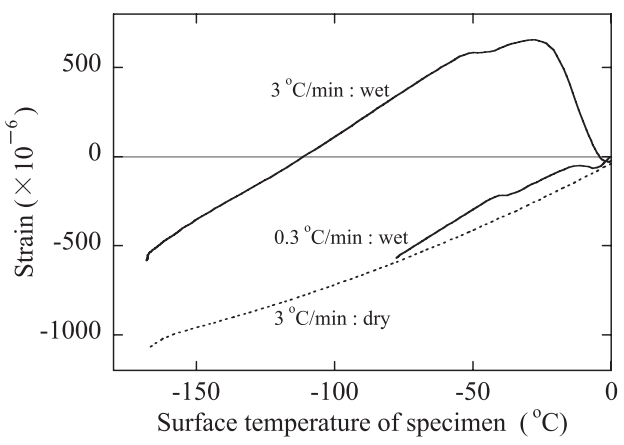

Fig.4 Relationship between surface temperature of specimen and strain.

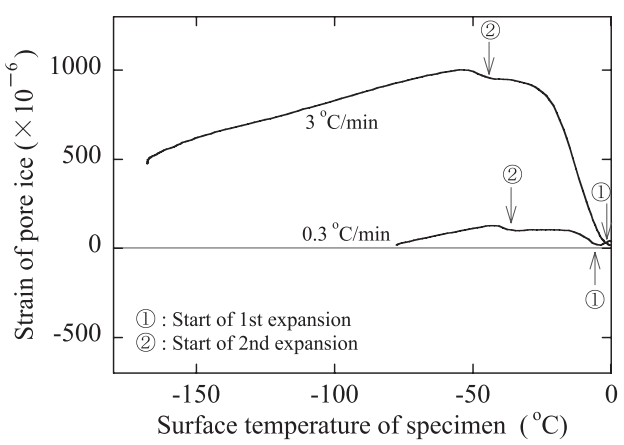

Fig.5 Relationship between surface temperature of specimen and strain of pore ice.

$\min$ では $-80^{\circ} \mathrm{C}$ を 1 時間保持した。供試体の含水状態は, 乾燥状 態と湿潤状態の 2 状態とした。なお，供試体は，含水比の変化を 避けるため, 内側にポリエチレン，外側にポリエチレンテレフタ レートを施した特殊ラミネートフィルム製の冷凍・耐湯バッグ ( 山本製作所製 heat seal bag，200×300mm，以降，heat seal bag と称す)に入れて密封し, 試験に供した。

\section{$2 \cdot 3$ 一軸圧縮試験，圧裂引張試験}

一軸圧縮試験, 圧裂引張試験には, 万能材料試験機 ( 東京衡機 製造所製 RUE-100 型）を用いた。一軸圧縮試験では，軸および 周ひずみを計測するため供試体に低温用ひずみゲージ ( 共和電業 社製 KFL-5-120-C1-11）を供試体側面中央に貼付け，得られた出 力ひずみに対しダミーゲージによる温度補正を行い，真ひずみを 求めた。

一軸圧縮試験，圧裂引張試験共に，室温 $\left(15^{\circ} \mathrm{C}\right),-10,-50$, $-100,-170^{\circ} \mathrm{C}$ の温度条件下で各 3 回行い, 乾燥状態 ( 飽和度 $0 \%$ ), 湿潤状態 (飽和度 $100 \%$ ) の含水条件下で行った。試験片の冷却は, 熱伝導率測定用低温槽を用い, 試験片の冷却速度を $3^{\circ} \mathrm{C} / \mathrm{min}$ と した。なお，恒温槽内部が所定の温度になった後，一時間保持し， 供試体内部の温度分布が一様になるのを待って試験に供した。供 試体の泠却時には，含水状態の変化を避けるため, heat seal bag に入れて密封した。一軸圧縮試験，圧裂引張試験の載荷は一定応 力速度で行い, 一軸圧縮試験では約 $0.7 \mathrm{MPa} / \mathrm{s}$, 圧裂引張試験て は約 $0.3 \mathrm{MPa} / \mathrm{s}$ ( 試験片直径方向に $850 \mathrm{~N} / \mathrm{s}$ ) とした。供試体の温度 変化を最小限に抑えるため, 載荷盤の周囲を断熱材で作製した簡 易低温槽で囲み, その内部を低温状態に保ち試験を行った。なお, 載荷時には，供試体を heat seal bag から取り出して行った。

\section{3. 実験結果および考察}

\section{$3 \cdot 1$ 線膨張ひずみ測定試験}

Fig. 3 に, 恒温槽内の雾囲気温度と試験片表面温度の関係につ いて示す。同図より乾燥砂岩を見ると, 冷却速度 $3^{\circ} \mathrm{C} / \mathrm{min}$ では表 面温度と䨌囲気温度の間に差が生じるが，冷却速度 $0.3^{\circ} \mathrm{C} / \mathrm{min}$ で は差が生じないことがわかる。この雾囲気温度と表面温度との差 は, 試験片内部の温度分布が一様でないことを示唆している。次 に, 湿潤砂岩をみると, 雾囲気温度が低下しているにも関わらず, 表面温度が $0{ }^{\circ} \mathrm{C}$ で停滞する現象が確認できる。この表面温度の $0^{\circ} \mathrm{C}$ での停滞は, 乾燥砂岩ではみられないことより, 間隙水が凍結寸 る際の潜熱による影響であると考えられる。さらに, 䨌囲気温度 $-100^{\circ} \mathrm{C}$ 以下 $\left(3^{\circ} \mathrm{C} / \mathrm{min}\right)$ または雾囲気温度 $-40^{\circ} \mathrm{C}$ 以下 $\left(0.3^{\circ} \mathrm{C} / \mathrm{min}\right)$ の灰色で示した範囲において, 湿潤砂岩と乾燥砂岩の曲線を比較 すると，曲線の傾きに差がみられる。この曲線の傾きは湿潤砂岩 の方が大きく, さらにこの傾きの差は, 速い冷却速度において顕 著である。この曲線の傾きの差は, 造岩鉱物と間隙水および間隙 内部の空気の熱伝導率の違いに起因寸るものと考えられる。

Fig. 4 に, 冷却速度 0.3 および $3^{\circ} \mathrm{C} / \mathrm{min}$ における湿潤砂岩のひ ずみ挙動を示す。同図には, 乾燥砂岩 (冷却速度 $3^{\circ} \mathrm{C} / \mathrm{min}$ ) につ いても示した。なお，乾燥砂岩では，冷却速度の違いは確認でき なかった。同図より，湿潤砂岩の表面温度一ひずみ曲線では，乾 燥砂岩ではみられない膨張ひずみが確認できる。この膨張ひずみ は, 速い冷却速度において大きく発生している。湿潤砂岩の冷却 過程でみられる膨張ひずみは, 間隙水の凍結に起因するものと考 えられる7）そこで, 湿潤砂岩のひずみから乾燥砂岩のひずみ を減算し, これを間隙水のひずみと仮定し, その挙動を検討した。

Fig. 5 に, 冷却速度 0.3 および $3^{\circ} \mathrm{C} / \mathrm{min}$ における間隙水のひず みを示す。同図より，ひずみは $-4^{\circ} \mathrm{C}$ 前後から (1 回目の) 膨張を 示した後一定となり，さらに表面温度が低下寸ると再び (2 回目) 膨張を示し，その後収縮に転じる挙動を示す。膨張ひずみの最 大值は $1000 \times 10^{-6}\left(3^{\circ} \mathrm{C} / \mathrm{min}\right), 130 \times 10^{-6}\left(0.3^{\circ} \mathrm{C} / \mathrm{min}\right)$ であり, 冷却速度で大きく異なる。また，膨張ひずみピーク時の試験片表 面温度は $-55^{\circ} \mathrm{C}\left(3^{\circ} \mathrm{C} / \mathrm{min}\right),-45^{\circ} \mathrm{C}\left(0.3^{\circ} \mathrm{C} / \mathrm{min}\right)$ 付近であり, 冷却 速度の遅速で多少の違いがみられる。この間隙水の膨張ひずみ の最大值は, 水の凍結による体積膨張 $9 \%$ と比較して極めて小さ い。この原因の一つとして Furuzumi らの仮説が挙げられる ${ }^{11)} 。$ Furuzumi らは, 湿潤岩石が完全に飽和せず, 空隙に空気が取り 残されたとし，間隙水凍結直後の空隙内部は間隙水・未凍結水・ 空気で満たされていると仮定している。この状態からさらに冷却 すると, 間隙水生成による体積膨張により未凍結水が押し出され, 空気の体積を圧縮し, 結果として試験片の膨張は小さくなると考 えられる。一方, 冷却速度を速くすると, 未凍結水が移動する前 に次々と間隙水が生成されるため, 空気を圧縮する間隙水の割合 


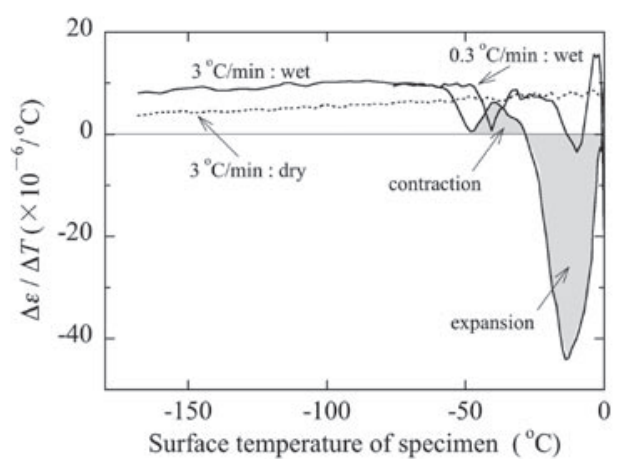

Fig.6 Relationship between surface temperature of specimen and linear expansion coefficient.

が減少し, 空隙を直接押し広げる割合が増加し, 結果として, 試 験片の膨張は大きくなると考えられる。

湿潤岩石の凍結澎張については, これまでにも報告されている 例えば7,12)。しかしながら，それらの報告は，湿潤岩石の凍結 ひずみを連続して測定したものではなく, 凍結膨張ひずみについ ても断片的にしか述べられていない。そこで, Fig. 5 をもとに, 湿潤砂岩の凍結メカニズムについて考察した。孔径が小さくなる と凍結温度は降下寸ることが知られている例えば 13)。また，水銀 ポロシメータによる測定結果 ${ }^{14)}$ によると, 来待砂岩は $100 \mu \mathrm{m}$ 以 上の孔と $0.1 \mu \mathrm{m}$ 以下の細孔の異なる孔径が確認されている。以 上のことより Fig. 5 の 2 回の凍結膨張ひずみは異なる孔径の間隙 水が凍結していると考えられる。また, 膨張ひずみピーク時の表 面温度が泠却速度で異なる原因は, 試験片内部の温度分布差に起 因する (Fig. 3 参照) と考えられる。

Fig. 4 より, 試験片表面温度一ひず夕曲線の傾きをとると Fig. 6 となる。この曲線の傾き, つまり単位温度変化 $(\Delta T)$ 当たりのひ ずみ変化率 $(\Delta \varepsilon)$ は, 線膨張係数と同じ次元をもつ。そこで本報 では, 立方体試験片より得られた試験片表面温度一ひずみ曲線の 傾き $\Delta \varepsilon / \Delta T$ を来待砂岩の線膨張係数として暫定的に扱うことに した。同図より, 冷却速度 $3^{\circ} \mathrm{C} / \mathrm{min}$ の試験結果をみると, 間隙 水の凍結現象がピークを迎えるまでの温度範囲内では, 表面温度 一線膨張係数曲線は複雑で一定の挙動を示さない。具体的には, 間隙水が 1 回目の凍結をほぼ終えるまでの温度範囲 $\left(0 \sim-30^{\circ} \mathrm{C}\right)$ において線膨張係数は大きな膨張を示す下に凸の曲線を描き, 2 回目の凍結を終える直前の温度範囲 $\left(-30 \sim-50^{\circ} \mathrm{C}\right)$ において線 膨張係数は収縮を示寸上に凸の曲線を描く。次に, 凍結現象がピー クを迎えた後の温度範囲 $\left(-50 \sim-55^{\circ} \mathrm{C}\right)$ において, 線膨張係数 は再度急激な収縮を示し, その後, 表面温度が $-70^{\circ} \mathrm{C}$ 以下になる と, 収縮を示す線膨張係数はほぼ線形的に減少する傾向を示す。 他方, 冷却速度 $0.3^{\circ} \mathrm{C} / \mathrm{min}$ の試験では, 表面温度 $-80^{\circ} \mathrm{C}$ における 線膨張係数に, 冷却速度 $3^{\circ} \mathrm{C} / \mathrm{min}$ との違いは無い。間隙水の凍 結がピークを迎えた後の表面温度 $-70 \sim-160^{\circ} \mathrm{C}$ 範囲における線 膨張係数は, ほぼ $10 \times 10^{-6} /{ }^{\circ} \mathrm{C}$ を示し, 一般的な岩石の低温下 における線膨張係数の範囲 $\left(0 \sim 10 \times 10^{-6} /{ }^{\circ} \mathrm{C}\right){ }^{15)}$ に収まってお り, 立方体試験片で得られた本測定結果は, 湿潤状態にある来待 砂岩の線膨張の指標として扱えると思われる。次に, 湿潤砂岩の 線膨張係数を乾燥砂岩のそれとで比較すると, 表面温度 $-70^{\circ} \mathrm{C}$ 以 下での湿潤砂岩の線膨張曲線の傾きは, 乾燥状態の傾きよりも小 さく, 表面温度 $-160^{\circ} \mathrm{C}$ における湿潤砂岩の線膨張係数 $\left(8 \times 10^{-6}\right.$ $\left./{ }^{\circ} \mathrm{C}\right)$ は, 乾燥砂岩 $\left(4 \times 10^{-6} /{ }^{\circ} \mathrm{C}\right)$ と比べ 2 倍程度大きい值を示し ていることがわかる。この原因として, 乾燥砂岩は造岩鉱物のみ の線膨張係数と考えられるのに対して, 湿潤砂岩は造岩鉱物と間

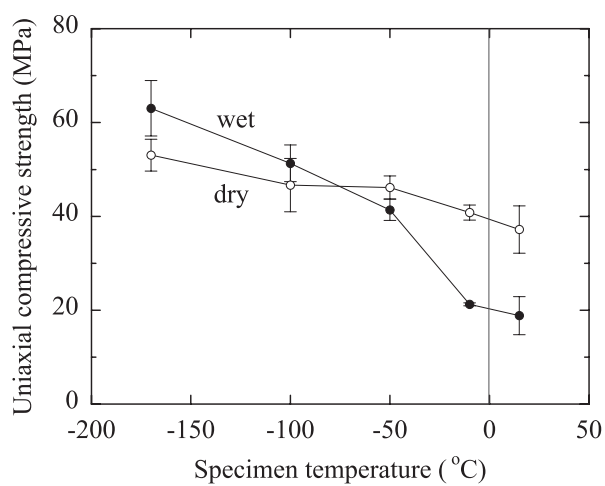

Fig.7 Relationship between specimen temperature and uniaxial compressive strength.

隙水の両者の線膨張係数を加算したものであると考えられる。

\section{$3 \cdot 2$ 一軸圧縮試験}

各試験片温度における来待砂岩の圧縮強度を Fig. 7 に示す。乾 燥砂岩の圧縮強度は, 試験片温度の低下にしたがいほぼ比例的に 増加する傾向を示し, $-170^{\circ} \mathrm{C} に お け る$ 圧縮強度は, 室温におけ る圧縮強度の約 1.4 倍まで増加している。一方, 湿潤砂岩の圧縮 強度においても, 試験片温度の低下にしたがい増加する傾向はみ られるが, その増加割合は乾燥砂岩と比較して非常に大きく, 複 雑な挙動を示している。具体的には, 湿潤砂岩の圧縮強度は, 間

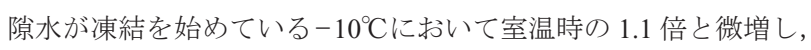

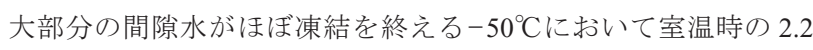

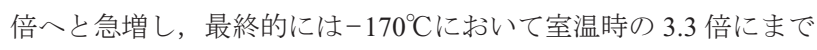
増加している。また, 湿潤砂岩と乾燥砂岩の圧縮強度を比較する と, 室温 $\left(15^{\circ} \mathrm{C}\right)$ において乾燥砂岩の半分程度である湿潤砂岩の 圧縮強度は, $-50^{\circ} \mathrm{C}$ において乾燥砂岩と同程度まで急増し, さら に- $170^{\circ} \mathrm{C}$ において乾燥砂岩の圧縮強度の約 1.2 倍まで増大寸る結 果となる。

これまで, 温度の低下における湿潤岩石の強度増加のメカニズ ムについては, 2 つ主たる要因があると考えられてきた 2, 7, 8)。 一つは, 間隙水の水点降下現象による孔径の大きい間隙から順に 水結寸ること, もう一つは水の強度が温度の低下にともない増加 することである。これら湿潤砂岩の強度増加メカニズムの要因は, Fig. 7 の結果より, 間隙水の最大膨張ひずみの温度を指標とする ことで $2 つ に$ 分けることができると考えられる。つまり，湿潤砂 岩の強度増加メカニズムについて, 間隙水の最大膨張ひずみが最 大となる $-50^{\circ} \mathrm{C}$ までの泠却過程では, 間隙水の凍結による間隙水 と造岩鉱物の複合体による荷重分担の効果の増加が主たる要因で あると考えられ, $-50^{\circ} \mathrm{C}$ 以下の泠却過程では, 間隙水の凍結はほ ぼ終えていると思われることより造岩鉱物と間隙水の体積収縮に よる圧縮強度の増加が主たる要因であると考えられる。

来待砂岩の乾燥状態における応力ーひずみ線図を Fig. 8 (a) に, 湿潤状態における応力ーひずみ線図を Fig. 8 (b) にそれぞれ示す。 同図には，各試験片温度について最も代表的な試験結果のみを記 している。Fig. 8 (a) より室温における乾燥砂岩の応力一軸ひずみ 曲線は, 試験片温度 $15^{\circ} \mathrm{C},-50^{\circ} \mathrm{C},-100^{\circ} \mathrm{C}$ において, 応力の増 加にしたがい弾性挙動から塑性挙動を経て脆性破壊に至る傾向 を示す。しかし, $-170^{\circ} \mathrm{C}$ では, 応力一軸ひずみ曲線は応力の増 加にしたがい弾性挙動から直接脆性破壊に至り, 塑性挙動は確 認できない。その結果，ヤング率を圧縮強度の $50 \%$ における応 カ一軸ひずみ曲線の接線勾配で求めると, 室温 $\left(15^{\circ} \mathrm{C}\right),-50^{\circ} \mathrm{C}$, $-100^{\circ} \mathrm{C}$ では $6.6 \mathrm{GPa}$ 前後で変化は見られず, $-170^{\circ} \mathrm{C}$ では $13 \mathrm{GPa}$ と約 2 倍に増加する。一方, Fig. 8 (b) より室温における湿潤砂岩 


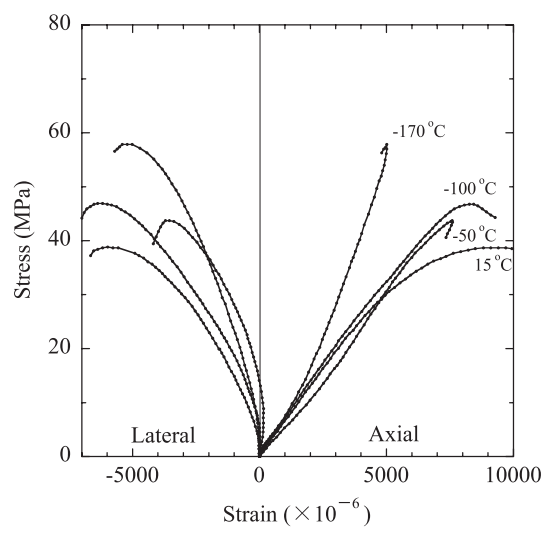

(a) Dry

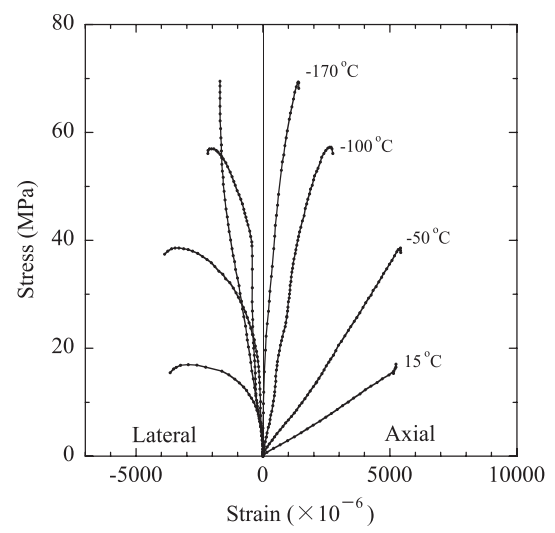

(b) Wet

Fig.8 Stress-strain curve in uniaxial compression test at various specimen temperature.

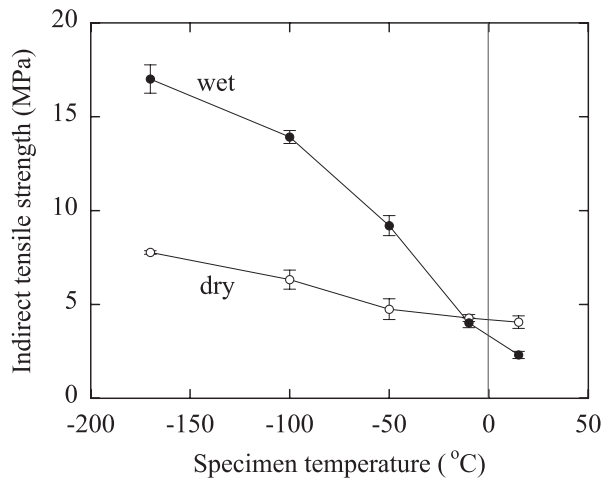

Fig.9 Relationship between specimen temperature and indirect tensile strength.

の応力ーひずみ曲線は, 乾燥砂岩と異なり, 弾性挙動を示したま ま直接脆性破壊に至る傾向を示す。また, これらのひずみ曲線は, 試験片温度によってその挙動が異なる。室温 $\left(15^{\circ} \mathrm{C}\right)$ と間隙水が ほぼ凍結を終える温度 $\left(-50^{\circ} \mathrm{C}\right)$ のひずみ曲線を比較すると, 温 度の低下にしたがい破壞強度は増加するが，破壊時の軸ひずみ． 周ひずみの值に変化は見られない。その結果, ヤング率は, $3.2 \mathrm{GPa}$ $\left(15^{\circ} \mathrm{C}\right), 8.1 \mathrm{GPa}\left(-50^{\circ} \mathrm{C}\right)$ と変化し, 温度の低下とともに増加する。 一方，間隙水がほぼ凍結を終えた以降の-50, $-100,-170^{\circ} \mathrm{C}$ を 比較すると, 温度の低下にしたがい, 破壊強度は増加し, 破壞時 の軸ひずみ・周ひずみの值は減少する挙動を示す。その結果，ヤ ング率は, $8.1 \mathrm{GPa}\left(-50^{\circ} \mathrm{C}\right), 42 \mathrm{GPa}\left(-100^{\circ} \mathrm{C}\right), 51 \mathrm{GPa}\left(-170^{\circ} \mathrm{C}\right)$ と変化し, 温度の低下とともに急增する。この湿潤砂岩でみられ るヤング率の急增や, 塑性挙動を経ずに直接脆性破壊に至る現象 は, 温度の低下により, 間隙水が体積收縮し硬化するためと考え られる。

\section{$3 \cdot 3$ 圧裂引張試験}

各試験片温度における来待砂岩の圧裂引張強度を Fig. 9 亿示 す。乾燥砂岩の引張強度は, 試験片温度の低下にしたがい増加す

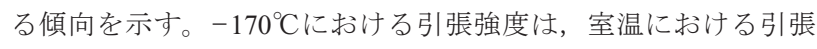
強度の約 2 倍まで増加し, この引張強度の増加は乾燥砂岩の圧縮 強度の増加 (1.4 倍) 上りも大きい。一方, 湿潤砂岩の引張強度に おいても, 試験片温度の低下にしたがい增加する傾向はみられる が, その増加は乾燥砂岩と比較して非常に大きい。具体的には,

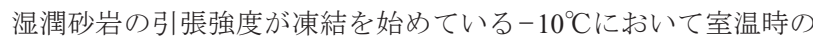
1.7 倍と増加し, 大部分の間隙水がほぼ凍結を終える $-50^{\circ} \mathrm{C} に お ~$

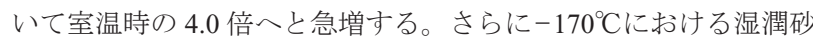
岩の引張強度は, 室温時の 7.4 倍にまで増加しており, 乾燥砂岩

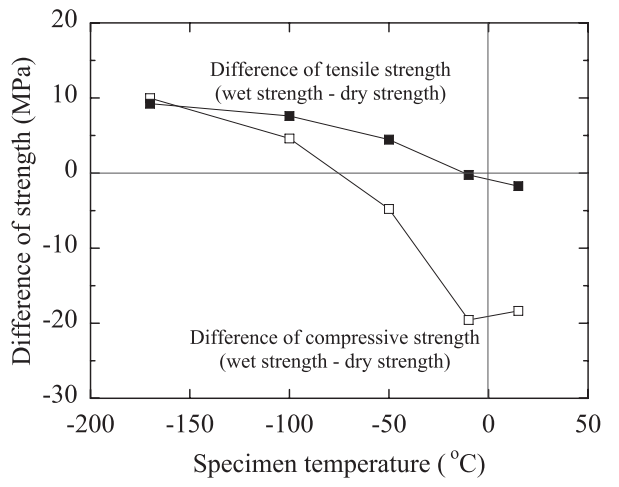

Fig.10 Relationship between specimen temperature and difference of strength.

の引張強度の増加 (3.3 倍) よりも非常に大きい。また, 湿潤砂岩 と乾燥砂岩の引張強度を比較寸ると, 室温 $\left(15^{\circ} \mathrm{C}\right)$ において乾燥 砂岩の半分程度である湿潤砂岩の強度は, $-10^{\circ} \mathrm{C}$ で乾燥砂岩と同 程度まで急増し, さらに- $170^{\circ} \mathrm{C}$ において室温時の乾燥砂岩の約 9.0 倍まで増大寸る結果となる。

間隙水凍結後の温度低下にともなう岩石の強度増加メカニズム は，造岩鈗物と間隙水の体積収縮による圧縮強度の増加が主たる 要因であると考えられる (Fig. 7 参照)。そこで, 温度の低下にと もなう水の強度増加による影響について検討した。具体的には, 一軸圧縮試験結果 (Fig. 7) と圧裂引張試駼結果 (Fig. 9) 上り, 温度 毎に湿潤砂岩の強度から乾燥砂岩の強度を減算し, この強度差を 間隙水が受け持つ荷重と仮定して, 強度差と温度低下の関係を検 討した。

Fig. 10 に, 各試験片温度における来待砂岩の強度差 (湿潤強 度一乾燥強度）を示寸。強度差は, 圧縮強度および引張强度とも に温度の低下にしたがい増加する。しかし, 引張強度と圧縮強 度とでは間隙氷の受け持つ応力に違いがみられ, 間隙水がほぼ 凍結を終える $-50^{\circ} \mathrm{C}$ にいて比較すると, 圧縮強度の強度差は約 $-5 \mathrm{MPa}$ であり, 引張強度の強度差は約 $5 \mathrm{MPa}$ である。また, 凍 結岩石の温度低下にともなう強度増加の主たる要因を間隙水の体 積収縮による氷の強度増加と仮定し, 間隙水がほぼ凍結を終える $-50^{\circ} \mathrm{C}$ を基準に間隙水の強度（強度差）の増加量を計算した。試 験片温度 $-170^{\circ} \mathrm{C}$ における圧縮強度の強度差は約 $15 \mathrm{MPa}$ の増加, 引張強度の強度差は約 $5 \mathrm{MPa}$ の増加となる。さらに，造岩釷物の 強度と間隙水の強度との間には線形加成則が成立すると仮定寸 る。本砂岩の有効空隙率は $24 \%$ でることから, 間隙水の圧縮 強度は $63 \mathrm{MPa}$ の増加, 引張強度は $21 \mathrm{MPa}$ の増加と算出される。 
一方, 多結晶水の一軸圧縮強度は最大でも $10 \mathrm{MPa}$ 程度であり, 引張強度は $1 \mathrm{MPa}$ 以下である ${ }^{16)}$ 。うまり, 試験片温度 $-170^{\circ} \mathrm{C}$ で は, 間隙水の方が多結晶水よりも圧縮強度で約 63 倍, 引張強度 で約 21 倍も大きいことになる。このことより, 間隙水凍結後の 温度低下にともなう凍結岩石の強度増加メカニズムは, 従来考え られてきた (Fig. 7 参照) 間隙水の体積収縮による強度の増加が主 たる要因と単純に結論づけることはできない。以上のことを踏ま えると, 今後, 温度低下にともなう凍結岩石の強度増加の要因と して, 間隙水による造岩鉱物の膠着効果や, 間隙水の噛み合わせ 効果について明らかにする必要があると考えられる。

最後に，欧米において試みられた凍結方式による LNG の岩盤 内貯蔵は, 熱応力によるクラックの発生などによって失敗に終

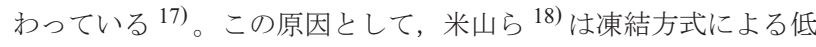
温岩盤貯蔵の成立条件について, 有限要素法を用いた熱力学と力 学の連成解析を行っている。その結果, $\operatorname{LNG}\left(-162^{\circ} \mathrm{C}\right)$ を貯蔵し た場合, 湿潤岩石の力学物性值の温度依存性と凍結膨張ひずみに よる影響で, 空洞壁面に引張破壊による破壊領域が発生し, この クラックから LNG が漏出することを明らかにした。さらに, こ の解析条件において, 米山らは凍結方式の適用可能な下限温度を $-60 \sim-80^{\circ} \mathrm{C}$ 程度であることを示唆した。

有限要素法による LNG 岩盤内貯蔵の力学的安定解析では, そ の運用に即して(1)岩盤内空洞掘削時の施工期間, (2)施設建設終了 時から極低温液化燃料貯蔵開始までのプレクーリング期間, (3)極 低温液化燃料貯蔵運転期間の 3 つ期間に分けて解析寸る必要が ある。(2)と (3)の期間における安定解析では, 始めに非定常熱伝導 解析を行い, 次に, 得られた経過時間における空洞周辺岩盤の温 度分布をもとに熱応力解析を行って, 得られた応力を岩盤の破 壊基準に照らし合わせることで力学的評価を行う。湿潤岩石の凍 結膨張による線膨張係数と, 凍結岩石の力学物性值における温度 依存性は, 熱応力解析においてその精度を左右する重要なファク ターとなる。すなわち, 本研究で明らかとした, 「湿潤砂岩の凍 結膨張メカニズム」と「温度低下にともなう凍結岩石の強度増加 の発現機構」を用いることで, 空洞周辺岩盤に生じる凍結膨張き 裂の分布を設計の段階で詳細に予測することが可能になると思わ れる。

\section{4. ま と め}

本研究では, 来待砂岩を用いて, 極低温までの冷却過程におけ る間隙水の凍結過程について検討した。次に, 間隙水の生成が砂 岩の力学物性にどのような影響を及ぼすのかについて検討した。 本研究で明らかになったことをまとめると以下のようになる。

線膨張ひずみ測定試験の結果

(1) 湿潤状態の来待砂岩を冷却すると, 凍結膨張が 2 回にわけて みられる。これより, 湿潤砂岩の凍結膨張メカニズムは, 孔 $(100 \mu \mathrm{m}$ 以上 $)$ と細孔 $(0.1 \mu \mathrm{m})$ の異なる $2 つ の 孔$ 径の間隙水が 異なる温度で凍結していると考えられる。
(2) 湿潤砂岩の表面温度一線膨張係数曲線について, 間隙水の凍 結現象がピークに至るまでの温度範囲内では, 線膨張係数は 増減を繰り返し，線形性を示さない。凍結現象がピークを越 えた以降の温度範囲では, 線膨張係数は収縮を示しほぼ線形 的に減少する傾向となる。

\section{一軸圧縮試験および圧裂引張試験の結果}

(3) 湿潤砂岩の圧縮強度は, 間隙水凍結初期の $-10^{\circ} \mathrm{C}$ において室 温時の 1.1 倍であるが，間隙水凍結がほぼ終了する $-50^{\circ} \mathrm{C}$ に なると室温時の 2.2 倍と急増し, $-170^{\circ} \mathrm{C}$ では室温時の 3.3 倍 まで増加する。

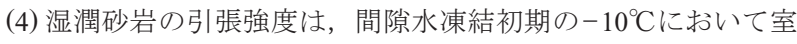
温時の 1.7 倍に増加し, 間隙水凍結がほぼ終了する $-50^{\circ} \mathrm{C}$ に なると室温時の 4.0 倍と急増し, $-170^{\circ} \mathrm{C}$ では室温時の 7.4 倍 まで増加する。この間隙水凍結による引張強度の増加は, 圧 縮強度の増加よりも顕著である。

(5) 湿潤砂岩の強度増加メカニズムについて, 間隙水凍結がほぼ 終了寸る $-50^{\circ} \mathrm{C}$ までの冷却過程では, 生成される間隙水と造 岩鉱物の複合体による荷重分担の効果の増加が主たる要因で あり, 間隙水の凍結がほぼ終了する $-50^{\circ} \mathrm{C}$ 以下の冷却過程で は，造岩鉱物と間隙水の体積収縮による圧縮強度の増加が主 たる要因であると考えられる。しかし, 試験片温度 $-170^{\circ} \mathrm{C}$ において間隙水の受け持つ応力は, 多結晶水の強度を大幅に 超えており, 間隙水凍結後の強度増加メカニズムについては さらなる検討を要する。

\section{References}

1) METI: Shin Kokka Enerugi Senryaku ni tsuite, (METI, Tokyo, 2006).

2) I. Matsunaga, M. Kuriyagawa and N. Kinoshita: Journal of MMIJ, 97 (1981) , 431-436.

3) Y. Ishizuka, N. Kinoshita and T. Okuno: Doboku Gakkai Ronbunshuu, 370III-5 (1986), 243-250.

4) Y. Inada, Y. Kohmura and T. Fujiwara: Doboku Gakkai Ronbunshuu, 445 III-18 (1992), 65-73.

5) Y. Inada, T. Fujiwara, S. Hatano and S. Kadota: Doboku Gakkai Ronbunshuu, 449III-28 (1994), 23-30.

6) Y. Inada and N. Kinoshita: Proc. 34th Symp. on Rock Mech., (2005), pp.165-170.

7) Y. Inada, N. Kinoshita, S. Seki, T. Matsuo, A. Nariyuki and K. Ochi: Doboku Gakkai Ronbunshuu, 547III-36 (1996), 211-220.

8) N.Kinoshita, S. Akagawa and A. Denda: J. Soc. Mat. Sci., Japan, 45 (1996), 242-248.

9) N. Kodama, Y. Fujii, S. Akagawa and Y. Ishijima: Doboku Gakkai Ronbunshuu C, 63 (2007), 24-33.

10) J. Kodama, T. Goto and Y. Fujii: Journal of MMIJ, 124 (2008), 733-740.

11) M. Furuzumi, Y. Takeshita, M. Kurashige, F. Nishimura, K. Hirose and K. Imai: Journal of Thermal Stresses, 27 (2004), 331-344.

12) A. Nakaya, N. Wakabayashi, H. Momota and H. Takasaki: Proc. 37th Symp. on Rock Mech., (2008), pp.409-414.

13) A. A. Antoniou: J. Phys. Chem., 68 (1964) , 2754-2764.

14) D. Nakamura, T. Goto, N. Mori, T. Suzuki and Hiramatsu: Japanese Geotechnical Journal, 1 (2006), 131-142.

15) JSCE: Thermally-Induced Engineering Problems in Underground Rock Structures Properties and Analysis-, (JSCE, Tokyo, 2006), pp.52-55.

16) N. Maeno and T. Kuroda: Seppyou no Kouzou to Bussei, (Kokon Syoin, Tokyo, 1986), pp.117-119.

17) E. Amantini, E. Chanfreau, and H. Y. Kim: LNG Journal, Mar./Apr. (2003) , 25-27.

18) K. Yoneyama, H. Momota, N. Wakabayashi and S. Okada: Proc. Symp. on Underground Space, 12 (2007) , pp.9-18. 